\title{
THE POST 1990 DIPLOMATIC PRACTICES OF NEPAL
}

\author{
Khadga K.C.* \\ Niha Pandey
}

\begin{abstract}
In $21^{\text {st }}$ century, the discourse of diplomacy has taken a new turn which has led to an emergence of advanced practices of Diplomacy. This alteration has influenced Nepal's diplomatic practices wherein the practice of diplomacy transformed immensely. With this note, this paper primarily focuses on the diplomatic practices of Nepal post 1990. It reflects on the relationship between the regime and the diplomatic practices in reference to the systemic and the state level of analysis. It further emphasizes on the Public Diplomacy as a significant aspect while conducting diplomacy in the $21^{\text {st }}$ century. Additionally, the analysis comprehends public diplomacy in relation with the democratic political structure. Next, Total Diplomacy is taken under scrutiny. The significance of Total Diplomacy in case of Nepal is discussed and the challenges of adapting Total diplomacy with the changing political structure are emphasized upon.
\end{abstract}

Key words: Public diplomacy, diplomatic practices, democratization, total diplomacy, panchayat regime, post-1990 regime.

\section{INTRODUCTION AND OBJECTIVE}

Diplomatic Practices in 1990's: Systemic Level of Analysis: Third Wave of Democratization

After 1990, the information and internet revolution changed the dynamics of Diplomacy in the international relations. In context to Nepal, the concept of New Diplomacy was pertinent where there was a widening content of diplomacy. What constitutes diplomacy today goes beyond the narrow politico-strategic conception (Barston, 2014, p. 1). The concept

* Dr. K. C. is an Associate Professor and Program Coordinator, Masters` in International Relations and Diplomacy (MIRD), and Miss Pandey is graduated in IRD and faculty at MIRD, TU. 


\section{THE POST 1990 DIPLOMATIC PRACTICES OF NEPAL}

of diplomacy no longer revolves around the tradition style of secrecy and autocracy. The overall thrust of diplomacy has evolved and the practice of diplomacy does not only confine to a particular aspect but overall or total aspects are taken into consideration. Hence, with this note, the diplomatic practice in the current era can be named as 'Total Diplomacy'. As stated by Chester Bowles, a former American diplomat, "We are coming to realize that foreign operations in today's world call for a total diplomacy" (Hamilton \& Langhorne, 2011, p.185). The international relations diplomacy has become total in a sense that the practices of diplomacy not only requires political aspects but also trade, technology, finance, development, terrorism, climate change and social issues are to be adapted efficiently to practice an effective diplomacy.

The representation of Fig (i) explains that the diplomatic practices of Nepal post 1990 has been defined in context to New Diplomacy which is referred to as an open practice mainly due to the third wave of globalization. The changes in the international structure followed by change in the regime have played an utmost role in defining the diplomatic practices. Firstly, the post 1990 diplomatic practices will be analyzed on the basis of the changes in the international system focusing primarily on internet and information revolution. Secondly, the influence of change in the regime in context to diplomatic practices will be discussed.

The key informant interview analysis portrays that the diplomatic practices post 1990 has been extensively guided by the nature of New Diplomacy. 55 percent of the respondent has explained that internet and information revolution has played a very significant role in changing the diplomatic practices. However, 45 percent of the respondents have examined that these aspects have not completely influenced the diplomatic practices of Nepal. The following graph represents the responses from the key informant interview in context to the information and internet revolution impacting on the diplomatic practices of Nepal. 
Fig. i: Extend to which Information and Internet Revolution Influenced the Diplomatic Practices Post 1990

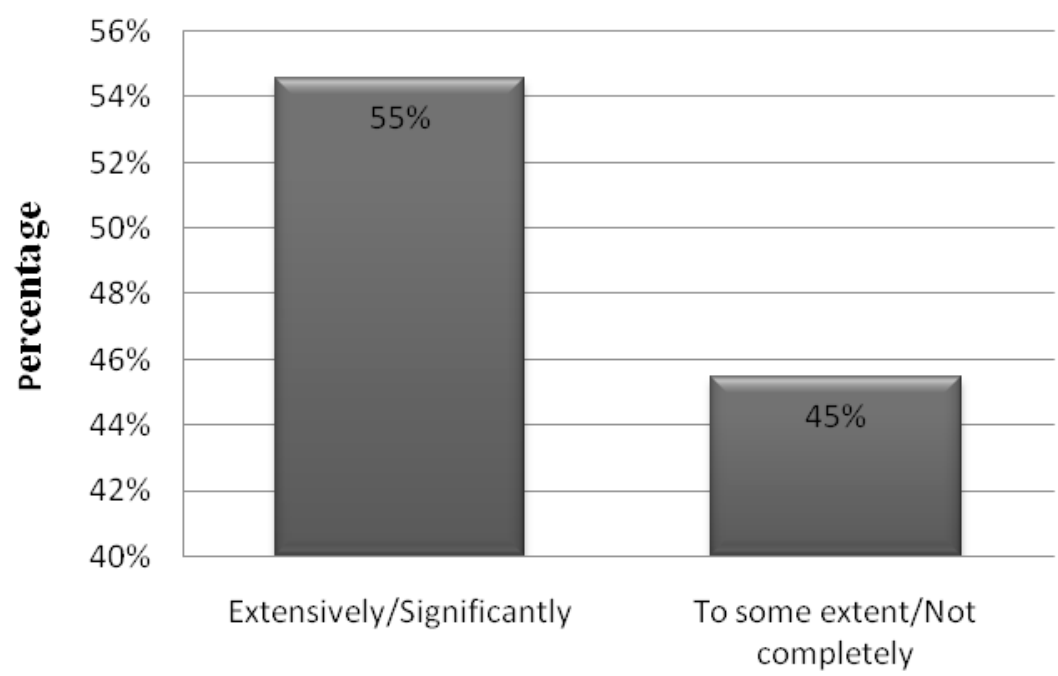

According to Sharma (a) (personal communication, June 2, 2017, Appendix), the nature of new diplomacy has highly influenced the military diplomatic practices because the feature of Military diplomacy has become trilateral and multilateral in character. This analysis clearly signifies that the diplomatic practices have changed its character from a bilateral relation to a multilateral relation. This enquiry posits that world is shifting towards multilateralism. As stated by Keohane (1990), Multilateralism is "the practice of coordinating national policies in group of three or more states." (p.731). Principally, Multilateralism signifies practice of diplomacy between three or more than three countries. As a consequence, the respondent emphasizes on the practice of diplomacy shifting to a multilateral nature which can be listed under the characteristics of New Diplomacy. Further on, to support his stance, he provides examples by describing on the Joint Military Trainings with many countries such as Britain, Pakistan, China and America. Similarly, Bhatta (personal communication, May 31, 2017, Appendix) also agrees on this stance by explaining that diplomatic practices post 1990 have very extensively been influenced and a country cannot limit diplomacy in state level mainly because of globalization. This has created a multi- dimensional change and Nepal's engagement in the international system clearly reflects the influence of both the revolution. 
Acharya (personal communication, May 26, 2017, Appendix) elaborates further on the instatenous and spontaneous availability of information. He portrays an example of Summit Diplomacy by indicating on how the conventional task has completely changed. Since, various actors are involved resulting to multi-level stakeholders. Due to this reason negotiations are conducted in every aspect such as climate change, terrorism, social issues, etc. It can be examined that there has been diffusion of diplomatic task and the head of the state itself has more decision in foreign policy. This designates that the diplomatic practice has resulted to conducting relation with the multi-level stakeholders within a multidimensional global governance structure. Similarly, Bhattarai (2017, Appendix) indicates that:

There has been a lot of changes since 1990. With the introduction of new technology there has been a lot of changes. Practicing of diplomacy in relation to Ministry of Foreign Affairs has had a remarkable change. There has been a revolutionary change, as prior to 1990, the diplomatic missions were only handled by the Ministry of Foreign Affairs but in the current operations, all the ministries are involved creating a networking among the ministries itself. (personal communication, June 8, 2017) Therefore, 55 percent of the respondents have responded to the fact that the internet and information revolution has highly influenced the diplomatic practices.

Understanding and analyzing further on the impact of these revolutions, 45 percent of the respondents explains that the influence in diplomatic practices has been insignificant or minimum in nature. As explained by Thapa (personal communication, June 8, 2017, Appendix), the influence is there but only to some extent. Post 1990 and especially after 2004-2005 internet became easily accessible and also affordable to Nepal. Since 1990, Nepal's diplomatic practice could be more technology oriented rather than human skill oriented. Similarly, Pandey (personal communication, June 25, 2017, Appendix) maintains that Nepal has not been influenced by these revolutions. He examined that Nepal has still not utilized the internet effectively creating a communication gap between Nepal and the rest of the world. He further adds that Nepal is still in the paper age. Therefore, these explanation holds on the perception that Nepal has not been able to effectively adapt itself with the changing technological dimension resulting 
to inefficiency in diplomatic practices. While studying the data accumulated from the respondent, it can be examined that the information and internet revolution right after the third wave of globalization and democratization has significantly impacted on the diplomatic practices but on the other hand it has not influenced in comparison to how it has influenced other states in international level. Analyzing the differences on the basis of the percentage, 55 percent of the respondent illustrated that the events in systemic level were the key reason for the influence in the diplomatic practices post 1990 but looking at the other side of the spectrum, 45 percent of the respondent emphasized that rather than the systemic level other factors relating to the regime type has played a crucial role in framing the diplomatic practices post 1990.

\section{State Level Analysis: Political Structure}

Proceeding further on the second part of the analysis, the oppositional politics that existed during the Panchayat regime came in to government introducing a new form of political structure titled as the multiparty democratic system. It can be examined that this new system influenced the state policy as well as the foreign policy. Thus, to accommodate foreign policy and diplomacy into the new system major challenges were faced. From 1960-1990 the foreign policy and diplomacy was practiced in an assertive nature where the palace secretariat played a chief role in formulation and implementation. Post 1990, the foreign policy and diplomacy were expected to operate from the MOFA but the investigation under the thematic analysis suggests that the functioning of foreign policy and diplomacy became more and more democratized and insignificant to the key state actors. There has also been an under performance resulting to a decline in Nepal's role in international forum post 1990. With this note, the following graphical representation will reflect the possible reason for Nepal's decline in the international forum, illustrating further on the role of the regime change as a major aspect for this declination. 
Fig. ii: Reasons for Nepal's declining position in international affairs in post -1990 Days

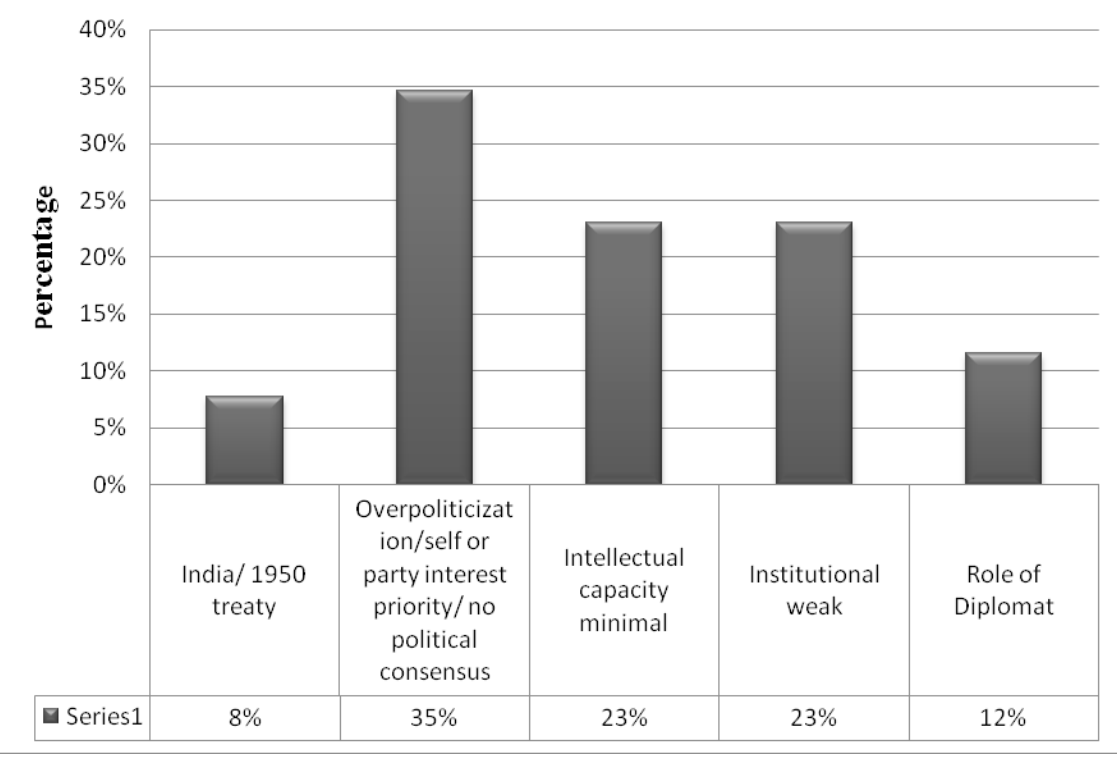

Connecting the relation between regime and diplomacy, this graph represents that the possible reasons that lead to Nepal's declining position were related to the aspects of regime structure. The highest percentage that illustrates the declining position can be categorized under the overpoliticization group. The term over-politicization can be understood as a concept which is driven heavily by the characters of politics. Diplomacy is one of the major tools of foreign policy and hence, foreign policy functions as per the national interests of a state. National Interests as defined under the French term raison d'état which is the aims and objectives of a country. Therefore, diplomacy is expected to be driven by the national interests of a country but in Nepal's case mainly after 2006, the foreign policy and diplomacy dimension is characterized as being over-politicized which operates on the basis of the interest of political party or self-interest. 35 percent of the key informant interviewers have responded that the major reason can be listed under the category of over-politicization. As referred by Thapa (personal communication, June 8, 2017, Appendix) post 1990, the diplomatic practice has functioned as per the narrow party interest rather than the national interests of Nepal. This illustrates on the lacking interest by key state actors on the foreign policy and diplomatic aspect of Nepal. Similarly, Dinesh Bhattarai (personal communication, May 30, 2017) further adds 
on the double standard nature and jingoism by the actors who have a key role in the diplomatic functioning. Elaborating further, the emphasis is has been put upon a double standard attitude by the major stakeholders of the diplomacy wherein jingoistic stance can be reflected eventually resulting to a negative impact.

Therefore, operating in context to national interests is a must in order to make a country's diplomacy effective. Bhattarai (6) (personal communication, June 13, 2017, Appendix) focuses primarily on the government institutions that operate under a democratic regime. He has demonstrated that there has been a massive interference in the Public Service Commission (PSC) which has led to this situation in current context. It elaborates further on the grounds of interference by political parties on the basis of their interest. Overall thrust behind this interference in due to the involvement of various actors in the states operation. Investigating further on the MOFA, Pandey (personal communication, June 25, 2017 , Appendix) explains that, Post 1990 the MOFA has been given a minimum priority. Appointment of ambassadors is in the backseat due to the vested self-interests and political interests of the state actors and no importance to the foreign ministry has been seen. Secondly, the appointment of the ambassadors completely resides on the hands of the political party that runs the government which is again an irrelevant practice. This reflects that the practice of democratic regime is given a different meaning which has impacted in the overall diplomatic function of the state.

Next, the politicization of the institutions has resulted to making the government institutions weaker. Every government sectors have been operating on the basis of the political parties' interest and thus, due to this selfish and self-centered interest the major state actors are not being able to come to a minimum political consensus. In case of role of diplomats, mainly the ambassador under the political appointment has functioned according to their political parties' interest thus; resulting to Nepal's declining position. 12 percent of the respondents have emphasized that the diplomats have not been able to function effectively because they are driven by the party's interest rather than the national interests. As Bhattarai (c) (May 30, 2017, Appendix) maintains that the credibility of diplomat has been a major question resulting to this situation. As stated by Apocryphal, "A diplomat is an honest man send abroad to lie for his country." (Khanal, 2015). Ambassadors are supposed to be diplomats who carry the agenda of accomplishing the interest of the country. But in the case of Nepal, the interest relies on the political party due to the political appointment 
hence, resulting to questioning on the reliability of the diplomat. When the diplomat itself is not under the conviction of the country, it is very rare to expect effective result. Hence, the role of diplomat has also been one of the crucial aspects for the weakening position of Nepal in the international arena.

Contemporary discussion of dependency and interdependence roots back to the early era of 1950's when Nepal signed the 1950 Treaty of Peace and Friendship between India and Nepal. This treaty has 10 articles along with the letter of exchange between the Prime Minister of Nepal Mohan Shumsher Jung Bahadur Rana and His Excellency Shri Chandreshwor Prasad Narain Singh. Now the context behind bringing this treaty in the forefront is the impact it has created in the diplomatic practices of Nepal. Few of the articles have questioned on the sovereignty of Nepal and hence, few of the key informant respondents have faulted the 1950 treaty to be the major hurdle in the diplomatic practices of Nepal. Respondents Sharma (a) (personal communication, June 2, 2017, Appendix) and Ghimire (personal communication, May 24, 2017, Appendix) demonstrated that India's involvement in the Nepal's politics has resulted to creating dependency towards India in diplomatic grounds. Ghimire also elaborates further that there has been series of compromise post 1990, hence, losing few aspects of the country's sovereignty. In statistical terms, 8 percent of the respondents have analyzed that the 1950 treaty has resulted to this current scenario. Therefore, in the current context, the treaty is under scrutiny with the effort of Eminent Persons' Group (EPG) which is supervised by Bhekh Bahadur Thapa from Nepal's side.

Additionally, two other major factors are advanced by 23 percent of the respondents to provide possible reason for Nepal's declined position. Firstly, post 1990, the intellectual capacity of the actors who operates the foreign policy and diplomacy is considered to be minimal. Secondly, again 23 percent respondents have also explained that the institutional weakness has been another major factor. As illustrated by Bhatta (personal communication, May 31,2017, Appendix), the modern governance paradigm are not discussed vibrantly and soundly which has led to this current scenario. The international system is not as same as how it was during the 60 's, 70's and 80's. Liberal democratic practices is practiced in major parts of the world and hence, discussions in a must to augment the intellectual capacity. Unfortunately, first and foremost, no discussions are seen in the parliament in relations to any diplomatic events plus the Institute of Foreign Affairs (IFA) is not effectively run. IFA was conceived as a catalyst body 
for generating national consensus on foreign policy issues and also to cater the professional training required by the Nepalese officials. (Institute of Foreign Affairs [IFA], 2012). Therefore, when institutes that operates as a wing to MOFA becomes ineffective; it eventually leads to impacting on the diplomatic practices of Nepal. Adding further to this, Bhattarai (b) (personal communication, May 30, 2017, Appendix) also emphasizes that the diplomatic machinery has weakened post 1990 resulting to the declined position of Nepal. In similar stance, Bhattarai (a) (personal communication, June 8, 2017, Appendix)) further adds that there has been lack of maturity in handling of the foreign policy and diplomacy which has been reflected in the current scenario. Likewise, Shambhu Simkhada (personal communication, May 26, 2017) stated that, 1990 leadership was so preoccupied with domestic politics that foreign policy was completely ignored. This has been reflected in both domestic and foreign politics of Nepal which has resulted to no code of conduct and no regulations ultimately leading to failure in various aspect of diplomacy. In similar tone, the diplomacy handling in the ministerial level has also been very weak, supports Sharma (personal communication, May 24, 2017, Appendix).

The think tank input has been minimum wherein the institutional memory is also zero. This overall examination evidently explains that institutional weakness and minimal intellectual capacity has been one of the possible reasons for declined Nepal's position in international arena. As a whole, in state level of analysis, the reflection of democratic nature in diplomatic practices can be examined. Democratic regime advocates of overall participation and inclusiveness in every sector of the government. However, in Nepal's case, the respondents have emphasized that the politicization in diplomatic arena has had a negative impact resulting to a Nepal's declined position in international.

\section{DISCUSSION AND RESULT}

\section{Comparing Public Diplomacy: Panchayat Regime and Post 1990 Regime}

Public Diplomacy is term first coined in 1965 as an American alternative to propaganda and is now perhaps too loosely applied to a whole gamut of activities, ranging from news briefing to nation-building (Hamilton \& Langhorne, 2011, p. 235). The concept of public diplomacy has evolved rapidly and is mainly focused to influencing a state with soft means. As defined by Paul Sharp," Public Diplomacy is a process in which direct relations with people in a country are pursued to advance the interests and 
extend the values of those being represented." (p. 106). This concept can be categorized under People-to-People (P2P) engagement. Public Diplomacy is one of the major features of Diplomacy of $21^{\text {st }}$ Century. In addition, Public Diplomacy's arsenal is considered as Soft Power. It emphasizes more on government involvement in promoting and participating rather than controlling the relations. Hence, Public Diplomacy helps to create a cross border network. There are three major elements of Public Diplomacy: Daily communications, strategic communication and maintaining relationship. Mainly, Public Diplomacy is practiced by listening, collecting/collating data about publics and their opinions overseas. Likewise, Public Diplomacy advocates certain ideas and interests to foreign public. Public Diplomacy is conducted via Cultural or Exchange Diplomacy and international broadcasting is also a major feature of Public Diplomacy. Therefore, the need for public diplomacy has been called for as it is targeted to reach out to the public and public related organizations in order to win positive opinion of the citizens of the country where the diplomats reside.

As Hocking perceives, "public diplomacy is now part of the fabric of world politics wherein NGOs and other non-state actors seek to project their message in the pursuit of policy goals.'(Mellisen, 2005, p. 41). While analyzing the Public Diplomacy concept, it can be examined as a form of political advertising. It is based on the idea of foreign government pursuing the public view. The functioning of Public diplomacy is based on listening, advocacy, cultural or exchange diplomacy and international broadcasting. Basically, the major thrust of Public Diplomacy is to communicate with foreign public in order to influence the foreign government in relation to policy making and implementation. In the recent development, foreign ministries have primarily focused on Public Diplomacy which clearly reflects that its adaptation is a must in the world affairs. For instance, attracting inward foreign investment or Foreign Direct Investment (FDI) and skilled migrant labor along with promoting trade and tourism requires a positive national image. Therefore, public diplomacy is one of the powerful diplomatic tools to achieve the interests of a state. Likewise, in the current development, "emphasis has been upon shaping and nurturing relationships among societies rather than between sovereign governments." (Hamilton \& Langhorne, 2011, p. 236). The relations of the foreign country are based on the society level which can be defined on the basis of public aspects. Moreover, the latest information and internet revolution has provided the diplomats with this tool for influencing and responding to public concerns. As a whole, Public Diplomacy is a two way communication based on 
maintaining relationship with the citizens and publics of the foreign country which is also labeled as Track Two diplomacy.

In Nepal's context, the conduct of Public Diplomacy has been an evolved practice and mainly post 1990, it has emerged under the democratizing process resulting to a new dimension which is practiced under the concept of New Public Diplomacy. Comparing Public Diplomacy under the timeframe of Panchayat Regime and Post 1990 regime, it has been examined that Post 1990 regime has been able to adapt and practice Public Diplomacy effectively. On the basis of the key informant interview, 73 percent of the respondents indicated that Public Diplomacy has been very well practiced mainly Post 1990 . However, in the other hand, 18 percent of the respondent explained that the Public Diplomacy was more effective during the Panchayat regime. Within this statistical analysis the focus can be inclined towards the Post 1990 regime.

As suggested by Thapa, (personal communication, June 8, 2017, Appendix)), Public Diplomacy has grown significantly mostly after 1990. The essence of democracy followed by the technological change has made the government more accountable and influenced by the public opinion. Thus, this has been a fundamental change in the practice of Public Diplomacy. Bhatta (personal communication, May 31, 2017, Appendix)) maintains that the major reason for effective Public Diplomacy post 1990 has been due to the third wave of globalization. In state level, the change in the regime to a multi-party democratic system created a mileage in public dimension building vibrant networks in the international forum.

Even Simkhada (personal communication, May 25, 2017, Appendix)) explains that Panchayat has had a very close circle so; Public Diplomacy is a new discourse which has been utilized more post 1990. Therefore, the significance of Public Diplomacy can be seen more prominently after the collapse of the Panchayat regime and the introduction of multi-party democratic system.

Conversely, few of the respondents have illustrated that Panchayat period adapted Public Diplomacy more effectively. Sharma (personal communication, May 24, 2017) elaborates that in numerical terms, the public diplomacy post 1990 has been zero. But looking back at the Panchayat regime, the diplomatic missions clearly reflects the effectiveness of public diplomacy. He asserts that the diplomats such as Bhekh Bahadur Thapa, were very vibrant to conduct public diplomacy flawlessly. In similar stance, Ghimire (personal communication, May 24, 2017, Appendix)) also 
explained that the diplomatic activities were confined to the elites who perceived indigenous wisdom. Therefore, this helped to frame a modern foreign policy creating a sound framework for functioning of diplomatic practices. All in all, it can be illustrated that the panchayat regime success in Public Diplomacy was due to the role of diplomats but the overall analysis reflects that Public Diplomacy after the post 1990 regime was more effective in comparison to the Panchayat era.

Now understanding the dynamics of Public Diplomacy along with the regime factor, it can be illustrated that the character of Public Diplomacy was highly suitable post 1990 due to which its influence was significant in the multi-party democratic regime. The nature of Public Diplomacy resides on the fact that it is more of a public engagement diplomatic practice which is only possible when a state adapts liberal institutions in order to achieve its interest. Simultaneously, it is important to understand that the public diplomacy should be a two way channel. Hence, to further understand this dimension a pie chart representation which is derived from the key informant interview is analyzed further.

Fig. iii: Public Diplomacy and Regime

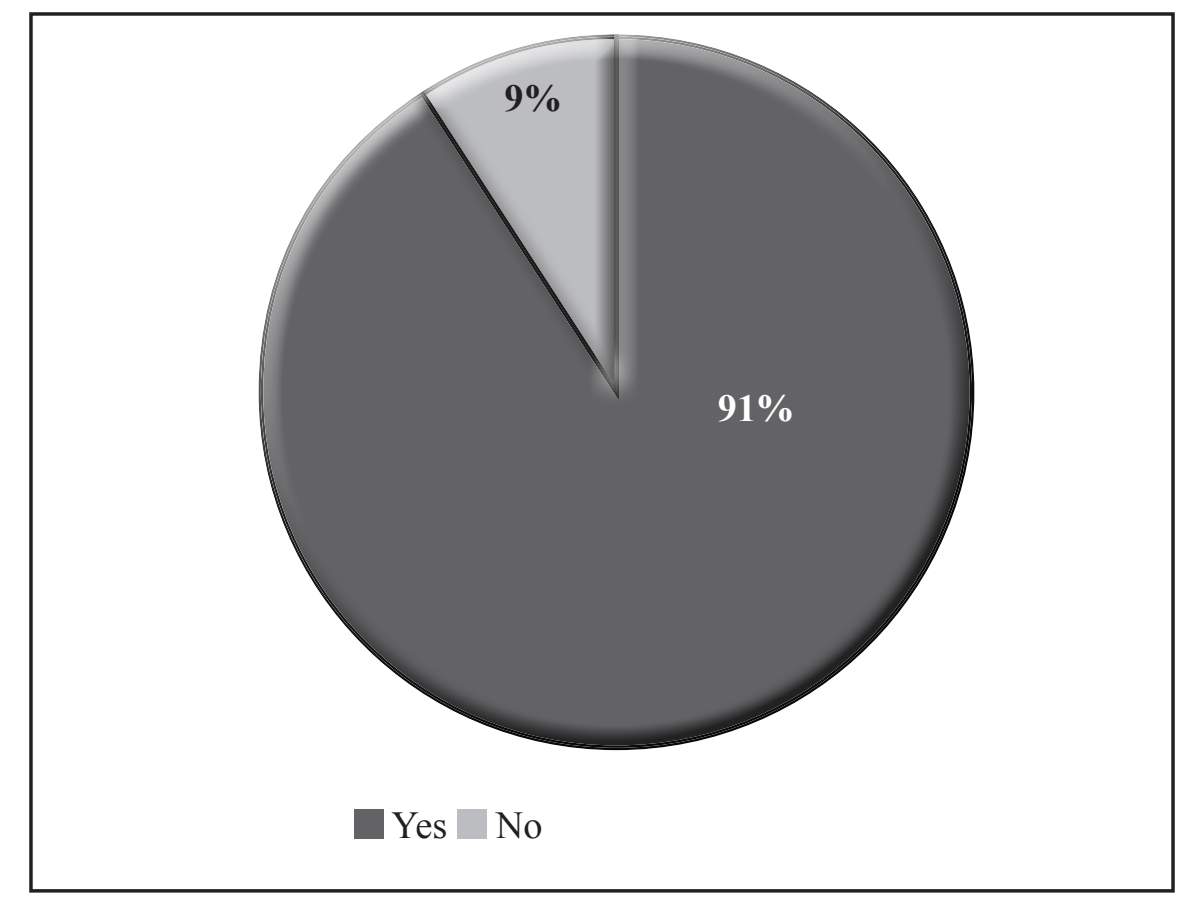


Representation portrays that Public Diplomacy is highly influenced by the regime factor. It illustrates that 91 percent of the respondents stated that Public diplomacy is greatly subjective to the regime. However, 9 percent of the respondents have demonstrated that Public diplomacy is not influenced by the regime style. Analyzing further on this perspective, Thapa (personal communication, June 8, 2017, Appendix) explains that public diplomacy is influenced by regime by providing an example of the recent development of One Belt One Road (OBOR). Nepal's participation in OBOR which was debated and there was a time when government was thought to be influenced by alternative view based on external pressure but then the public outcry was such that even a hesitant government had to be a party to the global interest and public demand. Therefore, public support was a major factor. Correspondingly, Bhatta (personal communication, May 31, 2017, Appendix) also explained by referring to both the regime. He explains that Panchayat regime has been covert in nature wherein the effective practice of Public Diplomacy was a major challenge. From Panchayat to multi-party democratic system there has been a major alteration in the practice of Public Diplomacy.

To add further to this understanding, Madhu Acharya (personal communication, May 26, 2017, Appendix)) explained that interest of regime is a major aspect when it comes to diplomatic practice, be it the practice of diplomacy in every aspects. Post 1990 was a period of democratic political organization where non-state actors played a very significant role. Therefore, there has been no luxury for secret deals creating a new dynamism but national interests have always been a basic parameter. In Nepal's case, regime has eventually influenced public diplomatic practices. Simkhada (personal communication, May 25, 2017, Appendix) adds further on this discussion by elaborating that the nature of regime has significant bearing on Public Diplomacy. Regime plays a chief role in the operational level of diplomacy and mainly in context to public diplomacy. Therefore, this analysis clearly portrays that the regime type has exceedingly impacted on the operations of Public Diplomacy.

\section{Total Diplomacy}

Total Diplomacy is a concept that arose due to the changing dynamics of international structure. It is a conduct of relations with the Multi-Polar world within the Multi-Level and Multi-Dimensional Global Governance structure. The increasing numbers of industrial, social and technological matters are perceived as having an international and therefore a diplomatic dimension. With the emergence of non-state actors, the dimensions of 
diplomacy have altered significantly. Comparing this concept with warfare, in early twentieth century, war was considered the only means to enhance state position and thus was illustrated as a total means to achieve national interests. Diplomacy was closely linked to grand strategy and was perceived no more than an extension of war by other means.

As illustrated, "In twenty-first century diplomacy became "total" in its objectives and subject matters." (Hamilton \& Langhorne, 2011, p. 185). Consequently, in this era, will, intelligence and resources are mobilized to a degree which would be exceeded only in total war. In sum, Total in a sense that, diplomacy requires not only political aspects but also trade, commerce,finance, terrorism, social issues, technology and development. The emancipation of third world along with the expansion of international organization and the broadening agenda of diplomatic practices has been analyzed in correspondence to the foreign services. By the mid- $20^{\text {th }}$ century, diplomacy became one of the booming industries in the world and in the current era, this boom has reached to its maximum height. An example illustrated in the book titled as "The Practice of Diplomacy: Its evolution, theory and administration" examines on the management of foreign policy. As illustrated by Hamilton and Langhorne (2011), "Thomas Jefferson managed the United States Foreign Policy with five clerks, two messengers and a part-time translator. But, by 1979 there were some 10,500 American foreign service employees" (p. 218). Within a span of almost 200 years the Foreign Service officers increased exponentially. This can be defined as a diplomatic inflation hence modifying the roles of diplomats. Moreover, the technological advancement and the speed of modern communication, mainly post 1990, have augmented the interdependence between states in both regional and global context. It outlines an increased activity in external affairs by domestic ministries.

This changing nature of diplomacy began right after the process of decolonization. The emergence of new sovereign states changed the political structure of a state. Similarly, the emergence of the new sovereign states was recognized by the UN. Around 60 countries which belonged to Asia, Africa and Latin America were officially recognized by the UN member states mainly after 1945 . This eventually lead to the emergence of new government institution and by the late $20^{\text {th }}$ century and early $21^{\text {st }}$ century the study of the conduct of diplomacy and its influence in the diplomatic practices came into prominence. Therefore, the study of modern diplomatic practices has increased in its horizon in relation to changing political structure. 


\section{Nepal and Total Diplomacy}

Total Diplomacy is an aspect that caters to different dimensions of diplomacy. Nepal, in context to Total Diplomacy has its own pros and cons. The adaptation of Total Diplomacy has become a major challenge to Nepal where the regime has changed time and again. From 1990-2005, Nepal was defined under the multi-party democratic system with a constitutional monarch but after 2006, the government system shifted to a new structure wherein a Federal Democratic Republic of Nepal was formed. With changes in the diplomatic dimension in international level and the shift in government structure in the state level, Nepal has been under immense challenge to adapt an effective diplomatic practice. In the modern age has Nepal adapted itself with this changing diplomatic discourse? This changing diplomatic discourse mainly caters to the dynamism of Total Diplomacy which goes beyond the conventional realism school of thought. It elaborates on practicing diplomacy with other actors which are not confined only to state actors. Correspondingly, power accumulation is not the prime national interests in the current era. Adapting an economically liberal policy, followed by being a part of global affairs is a compulsion in order to enhance relations among state as well as non-state actors. Therefore, according to the key informant respondent and the data derived from the interview, Nepal's adaptation with the Total diplomatic practices is elaborated below:

Fig. iv: Nepal and Total Diplomacy

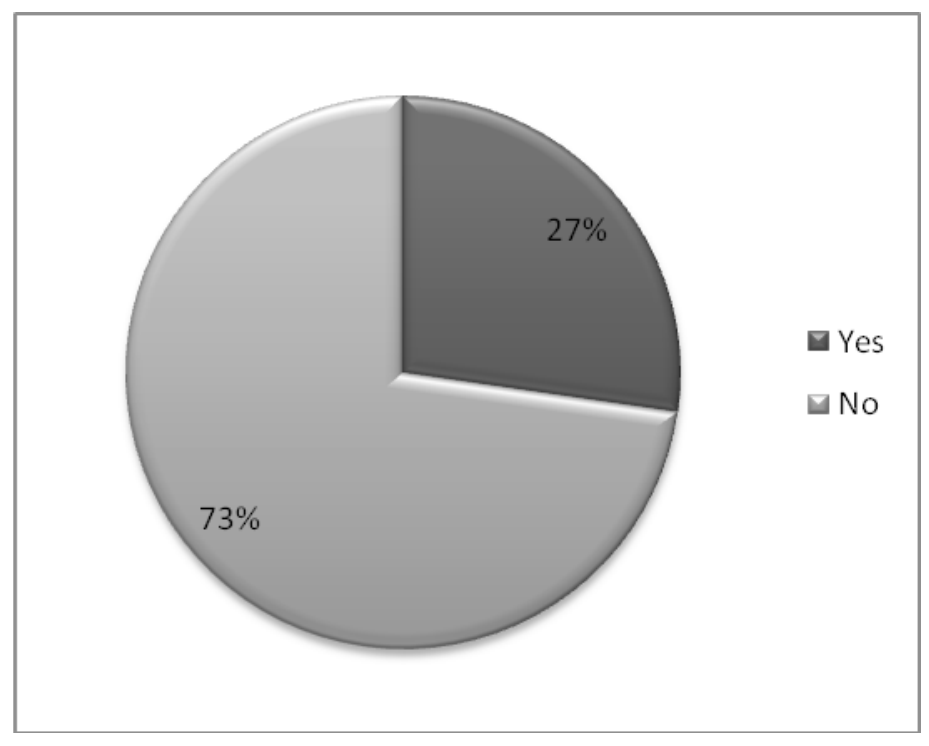


The expanded horizon of diplomacy has resulted to a Total Diplomacy which comprises almost all the aspects along with inclusion of various sectors and various ministries. The above figure interprets that 73 percent of the respondents revealed that Nepal has not been able to adapt with this changing diplomatic discourse. As explained by Thapa (personal communication, June 8,2017 , Appendix) this change is more external than internal. It has become a compulsion for all the states to become a party of the world rather than isolating itself. Unfortunately, Nepal's political conflict has been a major hindrance. Therefore, the changing regime context is a chief burden. So, a stable regime is required to look into national issues in respect to Total Diplomacy's context, rather than ones interest. Acharya (personal communication, May 26, 2017, Appendix) describes that we are heavily influenced by Total Diplomacy but we have not been able to internalize it. Even if a state is incapable or aspires not to adapt Total Diplomacy, the influence of it is felt in every regions of the world. The conduct of Total Diplomacy is more of a practice on diversified issue. Therefore, in Nepal's case we are highly influenced by it but we are not able to practice it effectively. As Simkhada (personal communication, May 25, 2017, Appendix) portrays and example by demonstrating that Nepal has not adapted this changing diplomatic discourse.He illustrates the role of NGO in Nepal's domestic political agenda. With so much of influence from the NGO's Nepal has not been able to recognize the importance of non-state actors. NGO's are one of the major actors of Total Diplomacy but Nepal is preoccupied with its internal politics that it has not yet realized its influence.

However, Bhattarai (personal communication, June 8, 2017, appenidx) describes that Nepal to some extent has been able to adapt itself with this changing diplomatic discourse. Post 2006, in the areas of counterterrorism, Nepal's security agenda towards the international system has become more prominent. In parallel justifications, Sharma (a) (personal communication, June 2, 2017, Appendix)) also agrees to the stance that Nepal to some extent has adapted Total Diplomacy mainly in case of involvement in various UN missions to counter terrorism. Additionally, the involvement of Nepal in Peacekeeping mission reflects a very good example when analyzing Nepal in context to Total Diplomacy. 


\section{Political Structure, Total Diplomacy and its Challenges}

Political structure can be defined in reference to the institutions that a regime adapts. Basically, it manifests the sovereignty of the country which constitutes of various institutions which is defined on the basis of regulations, laws and norms that is exhibited in the government system. Additionally, it also includes the development of credible strategies to effectively mobilize human and material resources. Briefly, it refers to the method in which a government is managed. Comprehending on the Total Diplomacy and political structure of Nepal, the post 1990 regime adapted a liberal model of institutions which was based on the ideals of Westphalia ministerial model. According to Article 56 of the Constitution of Nepal, the structure of the state is guided under Federal Democratic Republic. The executive power resides on the Council of Ministers (Article 75) and the President, under the Article 66 of the Constitution of Nepal, performs all the functions under the recommendation and the consent of the Council of Ministries. Hence, the President functions as a ceremonial role and the Prime Minister plays an executive role in the overall governance of the state. So far, Nepal has an immense experience of Parliamentary Model. From 1990-2016, Nepal has experienced various types of parliamentary model but this study will further analyze on the foundation of diplomatic practices irrespective to the parliamentary model.

Political structure and Total Diplomacy are two different dimensions. Political structure mainly caters to the operations of the government system whereas Total Diplomacy is an instrument to conduct diplomatic activities on issues that goes beyond the mere political aspects. To further opinionate on this ground, the major doubt arises on whether Nepal's political structure is motivated and guided by Total Diplomacy. Total Diplomacy encompasses issues and activities that does not limit only to the MOFA but other ministries along with the institutions plays a very crucial role to make its conduct more effective and vibrant. Derived from the key informant interview, 64 percent of the respondents have analyzed that the current political structure is not guided and motivated by Total Diplomacy. Sharma (a) (personal communication, June 2, 2017, Appendix) rationalizes that Nepal is not at all guided by Total Diplomacy. He presents a case of Gorkha Earthquake that took place in April 2015 where the institutions of the government were 
so weak to handle the foreign aid. Hence, Nepal Army was given the full authority to handle the situation rather than the MOFA taking the initiation. The ministry was unaware of the activities that were taking place. This clearly reflects that the political structure of Nepal has not prioritized Total Diplomacy in its operations. Likewise, Pandey (personal communication, June 25, 2017, Appendix) straightly emphasizes that post 2006; Nepal does not have the resources to guide itself in the facet of Total Diplomacy. Proper guidance from the political structure is a must in order to adapt Total Diplomacy effectively.

Nonetheless few of the respondents examined that Nepal's political structure is guided by Total Diplomacy. As mentioned by Bhattarai (a) (personal communication, June 8, 2017, Appendix), in economic sector the political structure post 1990 has implemented Total Diplomacy. He focuses mainly on the FDI and Nepal's role in World Trade organization (WTO) to visualize that Nepal's political structure to some extent has considered Total Diplomacy. In statistical terms, only 27 percent of the respondents elaborated on the political structure being guided and motivated by Total Diplomacy.

Consequently, to comprehend on this analysis, since Total Diplomacy comprises of multi-dimensional aspect which operates along which multiple stakeholder, various challenges arises while adapting it. For a country like Nepal, with changing political regime, time and again, implementing Total Diplomacy becomes a major challenge.

Table 1 : Challenges to Adopt Total Diplomacy

\begin{tabular}{|l|l|}
\hline Proportions & Percentage \\
\hline Politicization/lack political consensus & $33 \%$ \\
\hline Undefined National Interest & $4 \%$ \\
\hline Neighboring country's influence & $17 \%$ \\
\hline Institutionally weak & $33 \%$ \\
\hline Role of Diplomat & $4 \%$ \\
\hline Perception of the stakeholders & $8 \%$ \\
\hline Total & $\mathbf{1 0 0} \%$ \\
\hline
\end{tabular}

Source: Key informant, 2017. 
Drawn from the key informant interview 33 percent of the respondents have analyzed that politicization and institutional weakness has been a major challenge to adopt Total Diplomacy in Nepalese context. As explained by Thapa (personal communication, June 8, 2017, Appendix) a more accountable political process is required to practice Total Diplomacy. The current political context lacks that process. Bhattarai (c) (personal communication, May 30, 2017, Appendix) maintains that domestic preoccupation, jingoism and opportunism are the chief reasons to the current backdrop in diplomatic practices. Likewise, Simkhada (personal communication, May 25, 2017, Appendix) also holds a similar stance and explains that Total Diplomacy has been guided by political agenda resulting to politicization. Hence, due to this reason, the total diplomatic approaches are not practiced soundly and vibrantly. Lastly, within this stance, Sharma (b) (personal communication, May 25, 2017, Appendix) illustrates that political structure itself has become visionless because it has been guided by the interest of political agenda. Therefore, due to this reason, adapting Total Diplomacy has become one of the major challenges in the present period.

Proceeding further, institutional weakness has been another aspect to be analyzed on. Sharma (a) (personal communication, June 2, 2017, Appendix) demonstrates that the institutes are not well equipped. To support this view, Bhatta (personal communication, May 31, 2017, Appendix) explains by forwarding an example. IFA itself has become very weak and hence it is not run effectively. When the primary wing of the MOFA itself becomes weak then practicing total diplomacy becomes a major challenge. Bhattarai (b) (personal communication, June 13, 2017, Appendix) elaborates further by portraying that MOFA has no capacity to expand further in relation to increasing manpower resources. Second, in the current context, the institutes lack area of specialization, for instance, the labor force that is sent to the Middle East countries are having a very hard time because of the lack of expertise inmigration issues from the state level. Migration issue has become one of the major issues of Nepal and thus, migration is one of the chief aspects of Total Diplomacy.

Statistically, 17 percent of the respondents also specified that neighboring country's influence, particularly India, has been one of the 
challenges to adopt total diplomacy. Acharya (personal communication, May 26, 2017, Appendix) identifies about Nepal-China engagement in Nepal's diplomatic practices. There have been various events that portray that Nepal and China engagement has prompted India which has already become one of the most tedious operations to expand relations beyond the tradition relations. Even Pandey (personal communication, June 25, 2017, Appendix) agrees to this standpoint and explains on how the diplomatic practice of Nepal has been dominated by China and India. Overall, India's interest in Nepal has also been a major pull back factor for Nepal to adopt an effective Total Diplomacy. To conclude, the major challenges to adopt Total Diplomacy can be categorized under; politicization and lack of political consensus followed by undefined national interest, neighboring country's influence, institutional weakness, role of diplomat and perception of the stakeholder.

\section{CONCLUSION}

The overall analysis signifies that adapting Total Diplomacy is a major challenge because it encompasses various sectors along with multilevel stakeholders. The role of MOFA as well as the other Ministries also plays a very crucial role in adapting Total Diplomacy as a major foreign policy tool. Therefore, adapting total diplomacy itself in a rigorous work and in Nepal's case, since, the regime itself is more focused on the internal politics, concentration on these areas has been minimal. 
APPENDIX

\begin{tabular}{|c|c|c|c|c|}
\hline Name & Number & Date & Location & Time \\
\hline $\begin{array}{l}\text { Bala Nanda } \\
\text { Sharma (a) }\end{array}$ & Respondent 1 & $\begin{array}{l}\text { 2nd June, } \\
2017\end{array}$ & $\begin{array}{l}\text { Crisis } \\
\text { Management } \\
\text { College, } \\
\text { Dhumbarahi, } \\
\text { Kathamndu }\end{array}$ & 2:30PM \\
\hline $\begin{array}{l}\text { Bekh Bahadur } \\
\text { Thapa }\end{array}$ & Respondent 2 & $\begin{array}{l}\text { 8th June, } \\
2017\end{array}$ & $\begin{array}{l}\text { Nick-Simmons } \\
\text { Institue, Patan, } \\
\text { Lalitpur }\end{array}$ & 2:00PM \\
\hline Deepak Bhatta & Respondent 3 & $\begin{array}{l}\text { 31st May, } \\
2017\end{array}$ & $\begin{array}{l}\text { MIRD, } \\
\text { Buddhanagar, } \\
\text { Kathamandu }\end{array}$ & $\begin{array}{l}5: 00 \\
\mathrm{PM}\end{array}$ \\
\hline $\begin{array}{l}\text { Dinesh } \\
\text { Bhattarai (c) }\end{array}$ & Respondent 4 & $\begin{array}{l}\text { 30th May, } \\
2017\end{array}$ & $\begin{array}{l}\text { Hotel Annapurna, } \\
\text { Durbar Marg, } \\
\text { Kathmandu }\end{array}$ & $\begin{array}{l}2: 00 \\
\mathrm{PM}\end{array}$ \\
\hline $\begin{array}{l}\text { Madan } \\
\text { Bhattarai (b) }\end{array}$ & Respondent 5 & $\begin{array}{l}\text { 13th June, } \\
2017\end{array}$ & $\begin{array}{l}\text { Shital Niwas, } \\
\text { Kathmandu }\end{array}$ & $\begin{array}{l}3: 00 \\
\mathrm{PM}\end{array}$ \\
\hline $\begin{array}{l}\text { Madhu Raman } \\
\text { Acharya }\end{array}$ & Respondent 6 & $\begin{array}{l}\text { 26th May, } \\
2017\end{array}$ & $\begin{array}{l}\text { Olive and Basil } \\
\text { Café, Chakrapath, } \\
\text { Kathmandu }\end{array}$ & $\begin{array}{l}5: 00 \\
\mathrm{PM}\end{array}$ \\
\hline $\begin{array}{l}\text { Rajan } \\
\text { Bhattarai (a) }\end{array}$ & Respondent 7 & $\begin{array}{l}\text { 8th June, } \\
2017\end{array}$ & $\begin{array}{l}\text { Singha Durbar, } \\
\text { Kathamndu }\end{array}$ & $\begin{array}{l}4: 30 \\
\mathrm{PM}\end{array}$ \\
\hline $\begin{array}{l}\text { Ramesh Nath } \\
\text { Pandey }\end{array}$ & Respondent 8 & $\begin{array}{l}25 \text { th June, } \\
2017\end{array}$ & $\begin{array}{l}\text { Bishalnagar, } \\
\text { Kathmandu }\end{array}$ & $\begin{array}{l}\text { 10:00 } \\
\text { AM }\end{array}$ \\
\hline $\begin{array}{l}\text { Sambhu Ram } \\
\text { Simkhada }\end{array}$ & Respondent 9 & $\begin{array}{l}\text { 25th May, } \\
2017\end{array}$ & $\begin{array}{l}\text { Bansbari, } \\
\text { Kathmandu }\end{array}$ & $\begin{array}{l}10: 00 \\
\mathrm{AM}\end{array}$ \\
\hline $\begin{array}{l}\text { Sudhir Sharma } \\
\text { (b) }\end{array}$ & Respondent 10 & $\begin{array}{l}\text { 24th May, } \\
2017\end{array}$ & $\begin{array}{l}\text { Central Business } \\
\text { Park, Kantipur, } \\
\text { Kathmandu }\end{array}$ & $\begin{array}{l}5: 00 \\
\mathrm{PM}\end{array}$ \\
\hline $\begin{array}{l}\text { Yuva Raj } \\
\text { Ghimire }\end{array}$ & Respondent 11 & $\begin{array}{l}\text { 24th May, } \\
2017\end{array}$ & $\begin{array}{l}\text { Annapurna Post, } \\
\text { kathmandu }\end{array}$ & $\begin{array}{l}2: 00 \\
\mathrm{PM}\end{array}$ \\
\hline
\end{tabular}




\section{REFERENCES}

Barston, R. P. (2014). Modern Diplomacy(4th ed.). Third Avenue, New York: Routledge.

Hamilton, K., \& Langhorne, R. (2011). The Practice of Diplomacy: Its Evolution, Theory and Administration ( $2^{\text {nd }}$ ed.). Third Avenue, New York: Routledge

Institute of Foreign Affairs. (2012). Retrieved August 09, 2017, from http:// ifa.org.np/

Keohane, R. O.(1990). Multilateralism: an agenda for research. International Journal, 45(4), 731-764.

Khanal, P. (2015, August 3). Diplomacy: Meaning and Definition. Lecture presented at Lecture Powerpoint Slides in MIRD, Kathmandu.

Mellisan, J. (2005). The New Public Diplomacy . Macmillan: Palgrave.

Sharp, P. (2005). Revolutionary States, Outlaw Regimes and the Techniques of Public Diplomacy. In The New Public Diplomacy (pp. 106-123). Basingstoke, London: Palgrave. 